\title{
Identify the Presence and Source of Heavy Metal in Broiler Chicken Meat (Rajshahi Region, Bangladesh)
}

\author{
Md. Mahmudul Hassan Mondol ${ }^{1}$, Mithun R. Nath ${ }^{2}$, Badhan Saha ${ }^{1}$, Snahasish Bhowmik ${ }^{2 *}$, Manas Mondal ${ }^{3}$
}

${ }^{1}$ Bangladesh Council of Scientific and Industrial Research, Bangladesh

${ }^{2}$ Applied Chemistry and Chemical Engineering, Noakhali Science and Technology University, Noakhali, Bangladesh

${ }^{3}$ Ministry of Fisheries and Livestock, Government of the People's Republic of Bangladesh

DOI: $10.36347 /$ sjet.2020.v08i05.001

| Received: 20.01.2020 | Accepted: 27.01.2020 | Published: 30.05.2020

*Corresponding author: Snahasish Bhowmik

\section{Abstract}

Original Research Article

The present study was conducted to determine the level of the presence of heavy metal especially lead (Pb), chromium (Cr) and cadmium (Cd) in various body parts of broiler chicken (Liver, Bone, Core, Meat \& Skin) from the Rajshahi City local markets. All results show negative effect where the highest quantity of $\mathrm{Pd}, \mathrm{Cr}$ and $\mathrm{Cd}$ in feed is below the detection limit (BD), 0.0432, $0.0053 \mathrm{ppm}$ respectively. However, the highest quantity of $\mathrm{Pd}, \mathrm{Cr}$ and $\mathrm{Cd}$ in body parts of Chicken is 0.1313 in bone, 0.0977 and 0.0069 in skin which are safe for consumption considering the allowable WHO / FAO limit of $\mathrm{Pb}, \mathrm{Cr}, \mathrm{Cd}$ are $1.0 \mathrm{ppm}, 1.0 \mathrm{ppm}, 0.3 \mathrm{ppm}$ respectively. Moreover, mercury $(\mathrm{Hg})$ is a vaporized, molten metal that is vaporized at the cooking temperature. As a result we can be confident that the checked product was safe for consumption as an animal protein.

Keywords: Heavy Metals, Protein, Atomic absorption Spectroscopy, Vapourization, WHO, FAO.

Copyright @ 2020: This is an open-access article distributed under the terms of the Creative Commons Attribution license which permits unrestricted use, distribution, and reproduction in any medium for non-commercial use (NonCommercial, or CC-BY-NC) provided the original author and source are credited.

\section{INTRODUCTION}

High price and high cholesterol of Beef \& Mutton flesh, Chicken is becoming the key source of protein not only in Rajshahi but all of Bangladesh as well. Most of the people live below the poverty line, so they can't afford to buy high price protein source, but some research shown that toxicity in broiler chicken is particularly heavy metal. The heavy metal toxicity has been proven to be one of the major threats to human health [1]. The presence of heavy metal has shown toxic effects even at very low concentrations; its presence in foodstuffs can cause serious health problems such as central nervous disorders, anemia, damage to the kidneys and bones, cancer, glucosuria, osteomalacia etc $[2,3] . \mathrm{Pb}$ affects different systems in humans and causes neurological symptoms ranging from fatigue, headache and lethargy to peripheral neuropathy, severe seizures, encephalopathy and even coma [4, 5]. Furthermore, low concentrations of $\mathrm{Pb}$ can be found in tissues of clinically normal birds and animals [7]. Broiler chickens are vulnerable to inxication with $\mathrm{Pb}$. As low as $1.0 \mathrm{ppm} \mathrm{Pb}$ in the diet can cause significant growth suppression in chickens and consistent decline of D-aminolevulinic acid dehydratase in the blood which is a $\mathrm{Pb}$-sensitive erythrocyte enzyme [8]. Chicken-consumed $\mathrm{Pb}$ is accumulated in bones, soft tissues and eggs [8]. Pb bone levels are the highest by far, followed by liver and kidney. In the skeletal muscle the lowest $\mathrm{Pb}$ concentration is found [9]. Anthropogenic $\mathrm{Cd}$ is a priority pollutant to the atmosphere and an established risk to health [10]. The main consequence of long term exposure to $\mathrm{Cd}$ is permanent renal tubular dysfunction; the final and serious outcome is chronic renal failure even can cause damage to bones [5]. Ecotoxicological work has shown that marine birds that have their own breeding grounds in the northern hemisphere's arctic and subarctic regions have high levels of $\mathrm{Cd}$ that concentrate mainly in the highest concentration of kidneys and then in the liver at relatively lower concentrations [11]. Due to their key role in detoxification processes, ecotoxicological research on $\mathrm{Pb}$ and $\mathrm{Cd}$ accumulation has focused on the liver and kidneys in a poultry [11]. Nevertheless, with respect to the value of public health for these trace elements, determining their concentrations is important in the concept of other edible chicken giblets. Notably, $\mathrm{Pb}$ and $\mathrm{Cd}$, in particular, are seldom investigated in chicken giblets. The main goal of our research is to establish the presence of heavy metal in Food, to determine the reason for excess heavy metal if it is present and to make people aware of what they are consuming. 


\section{MATERIALS AND METHODS}

\section{MATERIALS}

All the reagents and chemicals used in the present work were purchased from Thomas Baker (Mumbai, India) and E. Merck (Germany) supplied by local vendors. All of the reagents are of analytical grade (i.e. purity higher than $99.9 \%$ ) and used without further purification. All glasswares, plastic wares used, were thoroughly washed with liquid soap, rinsed with distilled water, soaked in $10 \%$ nitric acid for 24hours, once again cleaned thoroughly with DDW and dried in such a manner to ensure that any contamination does not occur. All collected samples were stored in clean polyethylene bags, and used for analysis.

\section{METHODS}

Chicken feed was collected from a local shop and dried for $6 \mathrm{hr}$ into the oven, then grinded into a powder and mixed homogeneously for analysis. To assess heavy metal of chicken meat the chicken were also collected from the market of Rajshahi, shaheb bazar and binodpur bazar. Then all the parts of chicken and feed were hashed, dried at $95{ }^{\circ} \mathrm{C}$ and mineralized by wet digestion method $\left(\mathrm{HNO}_{3}-\mathrm{H}_{2} \mathrm{O}_{2}-\mathrm{H}_{2} \mathrm{SO}_{4}\right)$. Approximately $0.5 \mathrm{~g}$ of each dried sample was digested in $8 \mathrm{~mL} 65 \% \mathrm{HNO}_{3}$ for $3 \mathrm{ml} \mathrm{H}_{2} \mathrm{O}_{2}$ excluding bone sample. The bone sample was then digested in a microwave heating digester with $8 \mathrm{~mL} 65 \% \mathrm{HNO}_{3}$ and $2 \mathrm{ml} \mathrm{H}_{2} \mathrm{SO}_{4}$. The resultant solutions were analyzed with an atomic absorption spectrophotometer. Total process is presented in the Fig-1.

For each sample two replication determinations have been made.

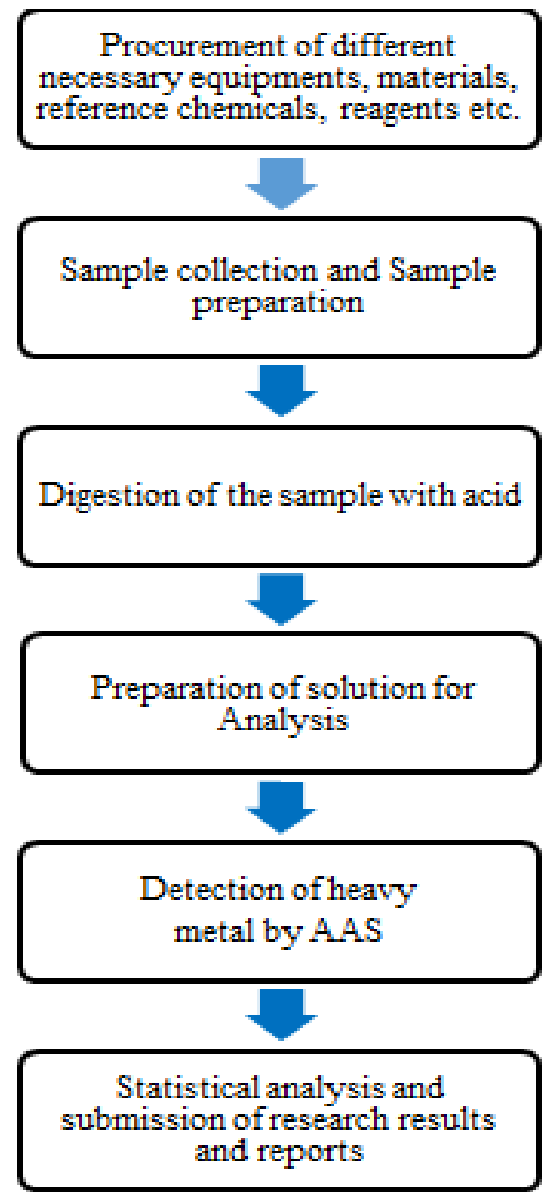

Fig-1: Flowsheet for sample preparation and sample analysis process

\section{RESULT AND DISCUSSION}

The present study reports on the heavy metal content of $\mathrm{Pb}, \mathrm{Cr}$, and $\mathrm{Cd}$ as determined by the collected Chicken in selected body parts (Liver, Bone, Heart, Meat \& Skin) and feed from market sites in the Bangladesh Rajshahi City Corporation district. The measured concentrations of $\mathrm{Pb}, \mathrm{Cr}$, and $\mathrm{Cd}$ in the chicken and feed were compared with the recommended limit set by the FAO / WHO in 2000 to determine the contamination levels of the food. The mean concentrations and variety of heavy metals found in chicken and feed collected from local markets in Bangladesh's Rajshahi City Corporate Area are given below: 
Table-1: Mean concentration of heavy metal in eight different type of feed

\begin{tabular}{|l|l|l|l|l|}
\hline \multirow{2}{*}{ Serial No } & \multirow{2}{*}{ Sample Name } & \multicolumn{3}{|c|}{ Selected heavy metal in ppm } \\
\cline { 3 - 5 } & & Pb & Cd & Cr \\
\hline 01 & Feed-1 & BD & 0.0038 & 0.0173 \\
\hline 02 & Feed-2 & BD & 0.0044 & 0.0243 \\
\hline 03 & Feed-3 & BD & 0.0044 & 0.029 \\
\hline 04 & Feed-4 & BD & 0.005 & 0.0243 \\
\hline 05 & Feed-5 & BD & 0.0044 & 0.0432 \\
\hline 06 & Feed-6 & BD & 0.0053 & 0.022 \\
\hline 07 & Feed-7 & BD & 0.0041 & 0.0243 \\
\hline 08 & Feed-8 & BD & 0.0039 & 0.0173 \\
\hline
\end{tabular}

Table-2: Mean concentration of heavy metal in selected five chicken meat

\begin{tabular}{|l|l|l|l|l|}
\hline \multirow{2}{*}{ Serial No } & \multirow{2}{*}{ Sample name } & \multicolumn{3}{|c|}{ Selected Heavy metal in ppm } \\
\cline { 3 - 5 } & & Pb & Cr & Cd \\
\hline 01 & Chicken -1 & 0.0113 & 0.055 & 0.0035 \\
\hline 02 & Chicken - & BD & 0.0507 & 0.0019 \\
\hline 03 & Chicken -3 & BD & 0.022 & 0.0032 \\
\hline 04 & Chicken -4 & BD & 0.0173 & 0.0038 \\
\hline 05 & Chicken -5 & 0.0112 & 0.055 & 0.0032 \\
\hline 06 & WHO/FAO MPL & 1.00 & 1.00 & 0.30 \\
\hline
\end{tabular}

Table-3: Mean concentration of heavy metal in selected five chicken bone

\begin{tabular}{|l|l|l|l|l|}
\hline Serial No & \multirow{2}{*}{ Sample name } & \multicolumn{3}{|l|}{ Selected Heavy metal in ppm } \\
\cline { 3 - 5 } & & Pb & Cr & Cd \\
\hline 01 & Chicken -1 & 0.1313 & 0.0432 & 0.0041 \\
\hline 02 & Chicken - & 0.1313 & 0.0196 & 0.0025 \\
\hline 03 & Chicken -3 & 0.1313 & 0.0314 & 0.0053 \\
\hline 04 & Chicken -4 & 0.0976 & 0.0102 & 0.0063 \\
\hline 05 & Chicken -5 & 0.1213 & 0.035 & 0.0024 \\
\hline 06 & WHO/FAO MPL & 1.00 & 1.00 & 0.30 \\
\hline
\end{tabular}

Table-4: Mean concentration of heavy metal in selected five chicken liver

\begin{tabular}{|l|l|l|l|l|}
\hline \multirow{2}{*}{ Serial No } & \multirow{2}{*}{ Sample name } & \multicolumn{3}{|c|}{ Selected Heavy metal in ppm } \\
\cline { 3 - 5 } & & Pb & Cr & Cd \\
\hline 01 & Chicken -1 & BD & 0.022 & 0.005 \\
\hline 02 & Chicken - & BD & 0.0243 & 0.0044 \\
\hline 03 & Chicken -3 & BD & 0.0173 & 0.0053 \\
\hline 04 & Chicken -4 & BD & 0.022 & 0.0041 \\
\hline 05 & Chicken -5 & BD & 0.0233 & 0.005 \\
\hline 06 & WHO/FAO MPL & 1.00 & 1.00 & 0.30 \\
\hline
\end{tabular}

Table-5: Mean concentration of heavy metal in selected five chicken heart

\begin{tabular}{|l|l|l|l|l|}
\hline \multirow{2}{*}{ Serial No } & \multirow{2}{*}{ Sample name } & \multicolumn{3}{|c|}{ Selected Heavy metal in ppm } \\
\cline { 3 - 5 } & & Pb & Cr & Cd \\
\hline 01 & Chicken -1 & BD & 0.0196 & 0.005 \\
\hline 02 & Chicken - & BD & 0.0203 & 0.005 \\
\hline 03 & Chicken -3 & BD & 0.0149 & 0.005 \\
\hline 04 & Chicken -4 & BD & 0.0163 & 0.0063 \\
\hline 05 & Chicken -5 & BD & 0.0196 & 0.005 \\
\hline 06 & WHO/FAO MPL & 1.00 & 1.00 & 0.30 \\
\hline
\end{tabular}


Table-6: Mean concentration of heavy metal in selected five chicken skin

\begin{tabular}{|l|l|l|l|l|}
\hline \multirow{2}{*}{ Serial No } & \multirow{2}{*}{ Sample name } & \multicolumn{3}{|l|}{ Selected Heavy metal in ppm } \\
\cline { 3 - 5 } & & Pb & Cr & Cd \\
\hline 01 & Chicken -1 & BD & 0.0856 & 0.0044 \\
\hline 02 & Chicken - & BD & 0.0196 & 0.0047 \\
\hline 03 & Chicken -3 & BD & 0.0977 & 0.0069 \\
\hline 04 & Chicken -4 & BD & 0.0149 & 0.0056 \\
\hline 05 & Chicken -5 & BD & 0.0267 & 0.0041 \\
\hline 06 & WHO/FAO MPL & 1.00 & 1.00 & 0.30 \\
\hline
\end{tabular}

The calculated concentrations of heavy metal were based on dry weight of the sample.

The mean concentration range of $\mathrm{Cr}$ and $\mathrm{Cd}$ in the feed sample, as shown in Table-1, is 0.0173 to $0.0432 \mathrm{ppm}$ and 0.0038 to $0.0053 \mathrm{ppm}$ respectively, where the amount of lead is below the detection limit. In some poultry feeds sold in Bangladesh, some researchers have reported that mean concentrations of heavy metals to include 0.1852-0.0232 ppm for cadmium, 20.6498-0.6019 ppm for lead and 5.7875$0.0926 \mathrm{ppm}$ for chromium $[12,13]$. It reveals that all the feed sample tested were safe for the poultry chicken.

Table- 2 contains the highest concentration of lead was identified in chicken meat known as muscle sample-1 is $0.1313 \mathrm{ppm}$, far below the WHO / FAO allowable limit [14]. The two concentrations of metals still remain below the allowable level of 0.0173 to $0.055 \mathrm{ppm}$ and 0.0019 to $0.0038 \mathrm{ppm}$ respectively of $\mathrm{Cr}$ and $\mathrm{Cd}[14]$.

The range of heavy metal selected to be tested in chosen sample were between 0.0976 to 0.1313 , 0.0102 to 0.0432 and 0.0024 to 0.0063 of $\mathrm{Pb}, \mathrm{Cr}$ and $\mathrm{Cd}$ respectively shown in table -3 . They were also well below the permissible limit set by WHO/FAO 2000 .

From the results in Table-4, among the five selected chicken sample liver contain below detection limit $\mathrm{Pb}$. Although others two element $\mathrm{Cr}$ and $\mathrm{Cd}$ can be detected but their concentration range between 0.0173 to $0.0243 \mathrm{ppm}$ and 0.0041 to $0.0053 \mathrm{ppm}$ respectively, which is also below the permissible limits.

In Table-5, we observed that the selected heavy metal range is 0.0149 to $0.0203 \mathrm{ppm}$ and 0.005 to $0.0063 \mathrm{ppm}$ of $\mathrm{Cr}$ and $\mathrm{Cd}$ respectively where the concentration of $\mathrm{Pb}$ is below detection limit.

The result shown in Table-6, mean concentration of heavy metal confines chicken skin ranges in between 0.0149 to 0.0977 and 0.0041 to $0.0069 \mathrm{ppm}$ of $\mathrm{Cr}$ and $\mathrm{Cd}$ metal. In this experiment, $\mathrm{Pb}$ also remain below detection limit.

To summarize all the results, it is shown that the levels of $\mathrm{Pb}$ in all body parts ranged between $\mathrm{BD}$ to $0.1313 \mathrm{mg} / \mathrm{kg}$. The range of $\mathrm{Cd}$ concentration $(0.0019$ $\mathrm{mg} / \mathrm{kg}$ to $0.0069 \mathrm{mg} / \mathrm{kg}$ and 0.010 to $0.0977 \mathrm{mg} / \mathrm{kg}$ ) in the current study was substantially lower than the $\mathrm{Cd}$ contents (2.67- $4.33 \mathrm{mg} / \mathrm{kg}$ ) found in chicken in Bangladesh in a study by Rahman et al., [15]. Cr also found in tested sample. Therefore, it can be concluded that all the result shows negative effect which means that the feed and chicken sample considered for being checked was safe and healthy.

\section{CONCLUSION}

In this study, the result reported here confirms that the possible accumulation of heavy metals $(\mathrm{Pb}, \mathrm{Cr}$ and $\mathrm{Cd}$ ) in broiler chicken tissue / organs originates from the feed. According to the results, the feed sample safe for poultry (Broiler chicken) and heavy metal accumulation $(\mathrm{Pb}, \mathrm{Cr}, \mathrm{Cd})$ in family poultry tissue / organs (Broiler chicken) has below the acceptable limits set by the WHO / FAO 2000, so chickens can be considered safe from this area for human consumption. To provide safe food or to maintain food safety certain type of investigation after a time interval is needed. Finally, this study can help poultry feed producers and poultry farmers provide nutrient-balanced, nutritious, safe, and cost-effective broiler flesh that continues to be a major protein source for consumers.

\section{ACKNOWLEDGEMENT}

The authors were grateful to Ministry of Science \& Technology, Bangladesh for financial support under the R\&D program (Project ID- Biology, Medical \& Nutrition12/766, 2018-19) to conduct this research. The author also thankful to BCSIR authority for Instrument support and scientist of BCSIR to give some advice in this research work.

Conflicts: Authors declare that there is no conflict of interest.

\section{REFERENCES}

1. Zeng-Yei H. Evaluating heavy metal contents in nine composts using four digestion methods, Bioresource Technology. 2004; 95:53-59.

2. Manju M. Effects of Heavy Metals on Human Health, Social Issues and Environmental Problems. September, 2015

3. Monisha J, Tenzin T, Naresh A, Blessy BM, Krishnamurthy N. Beeregowda, Toxicity, mechanism and health effects of some heavy metals, Interdiscip Toxicol. 2014 Jun; 7(2): 60-72.

4. Hossain A, Rahman MM, Saha B, Moniruzzaman M, Begum M. Heavy metal concentration and its 
toxicity assessment in some market fishes of Dhaka city, International Journal of Fisheries and Aquatic Studies. 2016; 4(3):523-527.

5. Ciobanu C, Slencu BG, Cuciureanu R. Estimation of dietary intake of cadmium and lead through food consumption. Rev Med Chir Soc Med Nat Iasi. 2012; 116:617-23.

6. Sharma RP, Street JC. Public health aspects of toxic heavy metals in animal feeds. J Am Vet Med Assoc. 1980; 177:149-53.

7. Doganoc DZ. Distribution of lead, cadmium, and zinc in tissues of hens and chickens from Slovenia. Bull Environ Contam Toxicol. 1996; 57:932-937.

8. Bakalli RI, Pesti GM, Ragland WL. The magnitude of lead toxicity in broiler chickens. Vet Hum Toxicol. 1995; 37:15-19.

9. Vengris VE, Mare CJ. Lead poisoning in chickens and the effect of lead on interferon and antibody production. Can J Comp Med. 1974; 38:328-35.

10. Revitt DM, Lundy L, Eriksson E, Viavattene C. Comparison of pollutant emission control strategies for cadmium and mercury in urban water systems using substance flow analysis. J Environ Manage. 2013; 116:172-80.

11. Kalisin' ska E, Salicki W. Lead and cadmium levels in muscle, liver, and kidney of scaupaythya marila from szczecin lagoon. Poland. Polish J Environ Stud 2010; 19:1213-22.

12. Islam MS, Kazi MAI, Hossain MM, Ahsan MA, Hossain AM. Propagation of heavy metals in poultry feed production in Bangladesh. Bangladesh Journal of Scientific and Industrial Research, 2007; 42(4): 465-474.

13. Alexieva D, Chobanova S, Iichev A. Study on the level of heavy metal contamination in feed materials and compound feed for pigs and poultry in Bulgaria. Trakia Journal of Sciences, 2007; 5(2): 61-66.

14. Working document for information and use in discussions related to contaminants and toxins in the GSCTFF [Internet]. Joint FAO/WHO food standards programme codex committee on contaminants in foods: fifth session; The Hague, The Netherlands; 2011 Mar 21- 25. Rome: Food and Agriculture Organization of United Nations; 2011 Mar [cited 2018 Oct 4]. 90. Available from: http://www.fao.org/tempref/codex/Meetings/ CCCF/CCCF5/cf05_INF.pdf

15. Rahman MA, Kamal S, Salam A, Salam MA. Assessment of the quality of the poultry feed and its effect in poultry production in Bangladesh. J Bangladesh Chem Soc. 2014;27(1\&2):1-9. 